\title{
Green Supply Chain Management in Vietnam Industrial Zone: Province-Level Evidence
}

\author{
Anh Duc Do', Quang Vinh NGUYEN², Quoc Hoi LE ${ }^{3}$, Van Loi TA ${ }^{4}$ \\ Received: April 25, 2020 Revised: May 03, 2020 Accepted: June 09, 2020
}

\begin{abstract}
The main purpose of this paper is to explore how green supply chain management (GSCM) and its evaluative factors have affected green supply chain management practice and performance in industrial zone. This study proposes a structural equation model of the relationships among four factors: internal awareness (IA); suppliers' pressure (SP); customers' awareness (CA); and regulations pressure (RP) and their effect on GSCM practice (PA) and GSCM performance (PE). We used a survey questionnaire to elicit perceptions/opinions about GSCM from three level of managers of 322 companies in Bac Ninh Province's industrial zones, Vietnam. PLS-SEM 3.0 software was applied to analyze and verify the gathered data, and the proposed hypothesis model. The results of path analysis show that internal awareness and customers' awareness are positively related to the GSCM practice and GSCM performance. However, suppliers' pressure and regulations pressure just impacted on GSCM practice. As a result, the testing of the relationship between GSCM practice and GSCM performance has been verified and supported. The findings of this study can help manager of companies in industrial zone understand the structure of GSCM, associate with the green supply chain management practice and green supply chain management performance, and be successful in green management organizations.
\end{abstract}

Keywords : GSCM Practice, GSCM Performance, Industrial Zone, PLS-SEM, Vietnam

JEL Classification Code:

\section{Introduction}

In recent decades, people are facing the challenge of finding a balance between sustainable economic development, and environmental damage. As the research of Shultz and Holbrook (1999) pointed out that balancing between economic and environmental performance has

${ }^{1}$ First Author. Lecturer, School of Trade and International Economics, National Economics University, Vietnam. Email: ducda@neu.edu.vn

${ }^{2}$ Vice Dean, Tourism Faculty, Hanoi University of Business and Management, Vietnam. Email: quangvinh191081@gmail.com

${ }^{3}$ Corresponding Author. Associate Professor, Editor-in-Chief, Journal of Economics and Development, National Economics University, Vietnam [Postal Address: 207 Giai Phong Road, Dong Tam Ward, Hai Ba Trung District, Hanoi, 113068, Vietnam] Email: hoilq@neu.edu.vn

${ }^{4}$ Associate Professor, School of Trade and International Economics, National Economics University, Vietnam. Email: loitv@neu.edu.vn

(c) Copyright: The Author(s)

This is an Open Access article distributed under the terms of the Creative Commons Attribution Non-Commercial License (http://Creativecommons.org/licenses/by-nc/4.0/) which permits unrestricted noncommercial use, distribution, and reproduction in any medium, provided the original work is properly cited. become increasingly important for organizations facing competitive, regulatory, and community pressures. In this case, supply chain management has received a greater attention by manufacturing organizations. Firms increasingly rely on their supply network to handle more complex technologies and higher customer expectation. As a result, integrating environmental concerns into green supply chain management has become increasingly important for manufacturers to gain and maintain competitive advantage (Zhu et al., 2008).

While the GSCM has become popular in the world for many years, especially in the US, the European Union (EU), Japan, and it has become an important concern for manufacturers. GSCM emerges as a new systematic environmental approach in green supply chain management and has been increasingly accepted and practices by forwardthinking organization (Bhool and Narwal, 2013). In a survey conducted in 17 countries with more than 13,000 respondents, about $70 \%$ of Japanese consumers were willing to accept paying 5\% higher prices, followed by Australia with 57\% and Singapore at $55 \%$ for green products (Vietnam Logistics Review, 2015). Although, this is an interesting development 
trend globally in recent years, GSCM is still a relatively new concept in Vietnam academic research.

Currently, Vietnam has 326 industrial zones established, with a total area of nearly 93,000 hectares. Of which, more than 250 industrial parks have been put into operation with occupancy rates of over $73 \%$. So far, the industrial parks and economic zones have attracted about 8,000 foreign direct investment (FDI) projects, the total registered investment capital is estimated at over USD145 billion and about 7,500 domestic investment projects, the total registered capital is estimated at nearly VND970 trillion. In the context of the Industrial Revolution 4.0, inputs such as cheap labor and abundant resources are no longer the strength of Vietnam, which urge center government and localities plan to develop green industrial zone with a suitable model to attract largescale projects and modern technology. Besides, the socioeconomic development strategy for the period of 2011-2020 in Decision No. 432/QD-TTg of the Prime Minister on approving the Vietnam Sustainable Development Strategy for the 2011-2020, Vietnamese Government has pointed out that the environment, in many places heavily polluted, resources, and land are not well managed, with inefficient exploitation and use. That situation poses a task for Vietnam to restructure the economy, implement in-depth growth model of transformation, and implement greening the economy to ensure sustainable development, including green production, green consumption, and green lifestyles.

Bac Ninh has become one of the leading provinces in the northern region of industrial zone development. After 20 years of construction, and development of industrial zones, Bac Ninh has 16 concentrated industrial parks approved and adjusted by the Prime Minister, with a total area of 6,397 hectares. In which, 10 industrial parks have been put into operation and attracted many large economic groups in the world, such as Samsung, Canon, Pepsi, ABB, Foxcon, etc. Green supply chain management is known as a form of environmental improvement. It is an operational initiative, which is adopted by many organizations to address such environmental issues.

There are many organizations in Bac Ninh, in particular, and in Vietnam, generally, which have undertaken significant efforts towards establishing green supply chain management initiatives. Lin (2013) has been concerned with the motivation and driving forces for these initiatives and examined these organizations although no previous research has tested an empirical link between such efforts and GSCM practices (Tseng et al., 2019). A review of the literature on green supply chain management published from 1998 to 2017 reveals that research on drivers or barriers analysis of green supply chain management is a declining trend. Le (2020) shows that in Vietnam, opinions of green supply chain as well as GSCM have not received strong attention by policy-makers, businesses, and researchers. The objective of this study aims to explore how GSCM and its evaluative factors have affected green supply chain management practice and performance in Bac Ninh Province's industrial zones, Vietnam.

\section{Literature Review}

Green supply chain management can be considered the involvement of the purchasing function in activities that include reduction, recycling, reuse and replacement of materials in the 1990s (Narashiman and Carter, 1998). Jain and Sharma (2014) showed that GSCM is a closed loop supply chain with minimal use of resources and is environment friendly. Moreover, Sarkis (2012) defined that GSCM as a combination of a revamped environmental and logistics company, which emphasizes the importance of reverse logistic. Do et al. (2020) showed that GSCM is the process of adding 'green' elements to existing supply chains and creating a recalled supply chain as a rebuilding system for a bright way. This includes not only on effective pursuit, but also innovation in the supply chain related to costs, profits, and the environment. Consumers increasingly expect from companies they purchase goods to ensure not only the quality and value-for-money, but also the environmental safeguard and social sustainability (Nguyen et al., 2014).

From product design to production process development and logistics management, the supply chain has a major impact on the environment, and simply trying to minimize the environmental footprint is not enough for companies to pursue the GSCM strategy. Zhu and Sarkis (2004) pointed out five GSCM practices include: internal environmental management practice, green suppliers' selection, cooperation with customers for green buying, investment recovery, and eco-design practices. To be accepted and successful, the strategy must bring great value throughout the company. GSCM is the integration of innovative and environmentallyfriendly methods into the supply process. In a standard supply chain process, economists have noticed growing concern about climate change and pressure on companies to reduce emissions. Holt and Ghobadian (2009) identified seven types of green supply chain initiatives that support companies in improving their environmental performance by classifying the organizations involved as follows: governments, trade associations and sector bodies, partnership groups, individual companies, business support organizations, nonfor-profit green business-support organizations, and green business clubs.

Nguyen et al. (2014) showed that, to ensure environmental excellence, top management must be totally committed. The support from middle managers is also essential to the successful implementation of GSCM practices as concluded by the study of Diabat and Govindan (2011), which found the positive relationships between middle- 
level managers' perceptions of corporate environmental proactivity and environmental management. Do et al. (2020) showed that communication between business managers and environmental professionals is also important in a successful business and environmental relationship. Chien and Shih (2007) noted that "it is important to evaluate the performance of GSCM inside the organization." Environmental performance is commonly measured through operative performance indicators, and management performance indicators (Cagno et al., 2011). Moreover, for companies that pay special attention to the performance of GSCM, internal environmental management (IEM) is more influential in stressing GSCM. For applied GSCM, all members in companies must be willing to embrace GSCM practice. Xue (2014) pointed out that since the 1990s, the studies within the production had focused on introducing the concept of green manufacturing supply chain, namely: (i) the concept and green manufacturing process; (ii) technologies and green manufacturing process; (iii) the applied research on green manufacturing; and (iv) the assessment of green manufacturing system.

Lin (2013) stated that "due to customer demands for green products, which are manufactured using environmentallyfriendly raw materials and green production process, firms have to integrate their environmental goals with long-term strategic management." Alves and Nascimento (2014) showed that reasons for the slow development of the GSCM concept in Brazil are related to the characteristics of the national market, businesses focus on internal aspects, and low consumer pressure. Other studies such as Nguyen et al. (2014), Do et al. (2020), and Do and Luu (2019), showed that consumer pressure certainly stimulates the environmental performance of all industries, while the growth of boutique eco-product suggests a growing clientele for such products, all organizations must ensure the sustainability of all components of their products.

Vachon and Klassen (2006) pointed out that the pressure from customers will improve the environmental performance of companies and encompass green procurement activities, such as setting an assessment criterion and evaluating the environmental performance of incoming goods, and the suppliers. Ricky and Lorett (2002) in the study comparing the green purchasing behaviors between American and Chinese consumers, showed that American consumers have more intention to align their behavior to green purchasing than Chinese consumers. However, Majumdar and Sinha (2019), analyzing the important barriers of green textile and apparel supply chain management in Southeast Asian countries, showed that concerted efforts regarding green technological innovation, consumers' awareness and support of the regulatory bodies are needed for effective implementation of green supply practices in textile and apparel supply chains.
Lee (2008), in the study of drivers in green supply chain initiatives, showed that cooperating with business partners in green supply chain initiatives is not an easy task. Alves and Nascimento (2014) emphasized that the GSCM involves supplier development, to share skills and risks, to adopt activities with cleaner technologies, appropriateness of specific rules and laws of the acting industry, reuse of materials, savings in water and energy, use of environmentally-friendly raw materials, production processes more streamlined, and flexible and responsibilities for all participants to the supply chain. It requires that the attitude towards these green initiatives may vary depending on their internal characteristics (Lee, 2008). Vachon and Klassen (2006), Sundarakani et al. (2010) argued that technology and innovation, transparency, and the enhancement of supplier relationships are important factors in the management of green supply chains, many factors that should be considered in green supply chain management. According to the theories mentioned above, the relationship with suppliers is the most important factor for GSCM. Furthermore, Ho et al. (2009) also indicated that building a good relationship with suppliers can benefit both parties when they work together to improve product design and product efficiency, which can lead to more waste reduction.

Zhu et al. (2008) concluded that the success of ecodesign requires internal, cross-functional cooperation within the company, and external cooperation with other partners throughout the supply chain. According to Vachon and Klassen (2006), it is better for corporations to establish long-term relationships with suppliers, which includes establishing requirements for product quality, following environmental regulations at the manufacturing level, having green packaging and distribution strategies and delivering high-quality products to customers (Xu and Gursoy, 2015). Majumdar and Sinha (2019) showed the importance of suppliers' role in term of GSCM, concluding their study that "Lack of green suppliers is the most dependent barrier which is influenced by all other barriers considered."

In considering why firms use green supply chains, a series of studies argued that compliance with regulations is a major driver that contributes to the implementation of green supply chains. Zhu and Sarkis (2004) divided the regulatory environment into three levels: regional environmental regulations, central government environmental regulations, and international environmental regulation agreements. To slow environmental degradation, sustainability is advocated (Jang et al., 2015). In considering this issue, developed countries took several measures, such as publishing certain laws and standards to control environmental impacts (Xu and Gursoy, 2015). However, in developing countries such as Vietnam, sustainability is still a new topic. Policies and approaches related to sustainability are incomplete, and the development of sustainability is at an early stage. 
However, Tseng et al. (2019) found a consistent growth in the evaluation of green supply chain management practices and performance.

Cousins et al. (2019) pointed out that GSCM practices are associated with improvements in both environmental, and cost-based performance. Furthermore, higher levels of eccentricity and supply chain traceability are associated with stronger relationships between GSCM practices and cost performance. The costs that pressure companies to apply GSCM include: cost for disposal of hazardous materials, cost of environmentally-friendly goods, and cost of environmentally-friendly packaging (Laosirihongthong et al., 2013). Based on the perspective of sustainable development supply chain, several factors that lead the industries practice the green supply chain management and its performance results, includes: Internal awareness, suppliers' pressure, customers awareness, cost related pressure, and regulations.

In the macroeconomic level, Balasubramanian and Shukla (2017), Wang and Dai (2018), and Le (2020) indicated the positive relationship of GSCM practice and economic, environmental, and social performance. Besides, Green et al. (2012), De Giovanni and Vinzi (2012) indicated that environmental management such as GSCM has a positive relationship with an organization's economic performance, operational performance (increase amount of goods delivered on time, decreased inventory levels, decreased scrap rate, promote products' quality, increased product line, improved capacity utilization) and environmental performance. Based on the literature review as well as previous studies, this research has come up with the following hypotheses:

$\mathrm{H}_{1}$ : Internal awareness has positive relationship with green supply chain management practice and green supply chain management performance

$\mathrm{H}_{2}$ : Suppliers' pressure has positive relationship with green supply chain management practice and green supply chain management performance.

$\mathrm{H}_{3}$ : Customers' awareness has positive relationship with green supply chain management practice and green supply chain management performance.

$\mathrm{H}_{4}$ : Regulations pressure has positive relationship with green supply chain management practice and green supply chain management performance.

$\mathrm{H}_{5}$ : Green supply chain management practice has positive relationship with green supply chain management performance

\section{Research Methods and Materials}

\subsection{Research Model}

Based on the literature discussed above, the technique for the creation of attributes for this research is based on the literature review, pilot sample, researcher's judgment, and experts. The structured questionnaire is employed. The communication approaches selected are both "survey via personal interview" and "self-administered survey."

For this study, we have chosen the form of interview as a method to collect data. Our goal is to collect 500 samples of survey questions from different units of companies in the Bac Ninh industrial zone, Vietnam. This study used a survey questionnaire to elicit perceptions/opinions about GSCM from managers. The survey instrument included questions seeking demographic information. The questionnaires were mailed to managers working in Bac Ninh Province's industrial zone from October 2019 to February 2020. SPSS 20.0 and PLS-SEM 3.0 software were applied to analyze and verify the gathered data, and the hypothesis developed.

This study reviews scholars' literature based on the research and practice of GSCM, the appropriate measurement scales of Zhu et al. (2008), Diabat and Govindan (2011), Cousins et al. (2019), Abdel-Baset et al. (2019), Chen et al. (2019), Esfahbodi et al. (2016), Laari et al. (2016), Mamdouh Mahmoud Hamdy et al. (2018), and information gathered from expert interviews (see Table 1).

The questionnaires were distributed firstly to 30 managers who were attending an MBA class in Vietnam National University and ten Professors on September 2019 to check how they understand the questions. Based on the suggestions from respondents in two workshops, minor modifications were made to the questionnaire. Afterward, questionnaires were revised and finalized and ready for collecting data.

500 questionnaires were distributed to managers at all levels who were working in Bac Ninh Province's industrial zone, 423 questionnaires were sent back of which 322 were valid, accounting for a response rate of $64,4 \%$. Table 2 shows the respondent information by nation, sector of industry, and number of employees.

The usable questionnaires were almost evenly distributed across national lines; among the 322 respondents $64.9 \%$ were Foreign companies and 35.1\% Vietnamese companies.

Companies into the automobile sector represented $16.1 \%$; those in the electrical and electronics, $54.7 \%$; the chemical sector accounting for $15.5 \%$; the textile sector, only $7.5 \%$; and the other sectors, $6.2 \%$.

Regarding the size of companies (represented by the number of employees), $21.7 \%$ had more than 1,000 employees, $46.9 \%$ had from 300 to 1000 employees, and $31.4 \%$ has less than 300 employees.

\section{Results and Discussion}

\subsection{Reliability and Validity of Model}

Construct validity, determined through the presence of convergent and discriminant validity, demonstrates how 
Table 1: Factors and items

\begin{tabular}{|c|c|c|c|}
\hline Factors & Items & Code & Source \\
\hline \multirow{4}{*}{$\begin{array}{l}\text { Internal } \\
\text { awareness }(\mathrm{IA})\end{array}$} & Awareness GSCM from senior managers & IA1 & \multirow{4}{*}{$\begin{array}{c}\text { Revised from Zhu et al. } \\
(2008) \text {, Cousins et al. } \\
\text { (2019), and Abdel-Baset } \\
\text { et al. (2019) }\end{array}$} \\
\hline & Awareness GSCM from middle managers & IA2 & \\
\hline & Awareness GSCM from functional managers & IA3 & \\
\hline & Cross-functional cooperation for environmental improvements & IA4 & \\
\hline \multirow{4}{*}{$\begin{array}{l}\text { Suppliers' } \\
\text { pressure (SP) }\end{array}$} & Supplier's advances in developing environmentally friendly goods & SP1 & \multirow{4}{*}{$\begin{array}{l}\text { Revised from Zhu et } \\
\text { al. (2008), Chen et al. } \\
\text { (2011), Esfahbodi et al. } \\
\text { (2016), Laari et al. (2016) } \\
\text { Mamdouh Mahmoud } \\
\text { Hamdy et al. (2018) }\end{array}$} \\
\hline & $\begin{array}{l}\text { Supplier's advances in developing environmentally friendly } \\
\text { packages }\end{array}$ & SP2 & \\
\hline & Environmental partnership with suppliers & SP3 & \\
\hline & Supplier's environmental mission & SP4 & \\
\hline \multirow{3}{*}{$\begin{array}{l}\text { Customers } \\
\text { awareness (CA) }\end{array}$} & Customer's demand for eco-design & CA1 & \multirow{3}{*}{$\begin{array}{l}\text { Revised from Zhu et } \\
\text { al. (2008), Diabat and } \\
\text { Govindan (2011), and } \\
\text { Chen et al. (2019) }\end{array}$} \\
\hline & Customer's demand for cleaner production & CA2 & \\
\hline & Customer's demand for green packaging & CA3 & \\
\hline \multirow{3}{*}{$\begin{array}{l}\text { Regulations } \\
\text { pressure (RP) }\end{array}$} & Central governmental environmental regulations & RE1 & \multirow{3}{*}{$\begin{array}{l}\text { Revised from Zhu et al. } \\
\text { (2008), An et al. (2008) }\end{array}$} \\
\hline & Regional environmental regulations & RE2 & \\
\hline & International environmental regulation agreements & RE3 & \\
\hline \multirow{3}{*}{$\begin{array}{l}\text { Green } \\
\text { supply chain } \\
\text { management } \\
\text { practice (PA) }\end{array}$} & Environmental management systems exist in companies & PA1 & \multirow{3}{*}{$\begin{array}{l}\text { Revised from Zhu } \\
\text { et al. (2008),Chen et } \\
\text { al. (2019),Laari (2016), } \\
\text { Mamdouh Mahmoud } \\
\text { Hamdy et al. (2018) }\end{array}$} \\
\hline & $\begin{array}{l}\text { Cooperation with suppliers for environmental objectives (friendly } \\
\text { goods and packages) }\end{array}$ & PA2 & \\
\hline & $\begin{array}{l}\text { Cooperation with customer for green design, produce and } \\
\text { packages }\end{array}$ & PA3 & \\
\hline \multirow{3}{*}{$\begin{array}{l}\text { Green } \\
\text { supply chain } \\
\text { management } \\
\text { performance } \\
\text { (PE) }\end{array}$} & Improve an enterprise's environmental situation & PE1 & \multirow{3}{*}{$\begin{array}{l}\text { Revised from Zhu et al. } \\
\text { (2008), Esfahbodi et al. } \\
\text { (2016), Laari et al. (2016) } \\
\text { Mamdouh Mahmoud } \\
\text { Hamdy et al. (2018) }\end{array}$} \\
\hline & $\begin{array}{l}\text { Increase products' quality and quantity and Improved capacity } \\
\text { utilization }\end{array}$ & PE2 & \\
\hline & Increase profit, market share and save cost & PE3 & \\
\hline
\end{tabular}

A five-point scale: $1=$ not at all, $2=a$ little, $3=$ to some degree, $4=$ relatively significant and $5=$ significant

Table 2: Respondent information

\begin{tabular}{|l|c|c|c|}
\hline \multicolumn{2}{|c|}{} & Frequency & Percent \\
\hline Nation & Foreign & 209 & 64.9 \\
\cline { 2 - 4 } & Vietnam & 113 & 35.1 \\
\hline \multirow{5}{*}{ Sector of industry } & Automobile & 52 & 16.1 \\
\cline { 2 - 4 } & Electrical and electronic & 176 & 54.7 \\
\cline { 2 - 4 } & Chemical & 50 & 15.5 \\
\cline { 2 - 4 } & Textile & 24 & 7.5 \\
\cline { 2 - 4 } & others & 20 & 6.2 \\
\hline \multirow{3}{*}{$\begin{array}{l}\text { Size (Number of } \\
\text { employees) }\end{array}$} & $>1000$ & 70 & 21.7 \\
\cline { 2 - 4 } & $300-1000$ & 151 & 46.9 \\
\hline Total & $<300$ & 101 & 31.4 \\
\hline
\end{tabular}


well the measurement items related to the constructs. To demonstrate convergent validity, we use three tests: item reliability, composite reliability, and average variance extracted.

Cronbach's alpha also provides evidence of composite reliability and values above 0.6 , demonstrating that it is adequate. All the composite reliabilities for our constructs were above 0.7 and all the Cronbach's alpha are above 0.6 (see Table 3). Finally, the average variance extracted (AVE) represents the amount of variance a construct captures via its items relative to the amount of variation dues to measurement error. We found that each construct's variance extracted was above the recommended value of 0.5 (Hair et al., 2016).

For testing the discriminant validity this paper used two tests for discriminant validity: comparison of item loadings with item cross loadings and comparison of the variance extracted from the construct with shared variance. Each item should load more highly on its intended construct than on other constructs. Results from Table 4 find that all items satisfied the condition of discriminant validity.

\subsection{PLS Structural Model Results}

To examine the overall explanatory power of the structural model and the variance explained by the independent variables, and the magnitude and strength of its paths, each of our hypotheses corresponds to a specific structural model path.
We used $\mathrm{R}^{2}$ Adjusted to measure the model's explanatory power, interpreted in the same way as for the regression analysis. The explained variation should exceed $10 \%$ to qualify for suitable explanatory power. The analysis revealed that the structural model explained about $57 \%$ of the variation of GSCM practice and 45\% GSCM performance suggesting that the structural model provided adequate explanatory.

Table 5, shows that other indices also have the goodness index such as VIF value of all variables in the model is less than 3 (Hair et al., 2014), so there is no multicollinearity problem. The value of $\mathrm{f}^{2}$ function represents the level of influence of the structure (factor) when removed from the model. Structures with small $\mathrm{f}^{2}$ values (less than 0.02 ) demonstrate a low level of influence in the model. In this model the result indicated that all relationship is highly influential $\left(\mathrm{f}^{2}>0.02\right)$.

Results from Table 6 and Figure 1 indicate that three of five hypotheses in our conceptual model are fully supported, two hypotheses are partly supported.

$\mathrm{H}_{1}$ shows that internal awareness has positive relationship with green supply chain management practice $(\beta=0.2$, $\mathrm{t}=2.88, \mathrm{P}<0.01)$ and green supply chain management performance $(\beta=0.28, \mathrm{t}=4.93, \mathrm{P}<0.01)$. This result shows that if internal awareness by senior managers, middle managers and functional managers of the benefit of GSCM is improved, so the GSCM practice and performance also improved.

Table 3: Construct Reliability and Validity

\begin{tabular}{|l|c|c|c|c|}
\hline & Cronbach's Alpha & rho_A & $\begin{array}{c}\text { Composite } \\
\text { Reliability }\end{array}$ & $\begin{array}{c}\text { Average Variance } \\
\text { Extracted (AVE) }\end{array}$ \\
\hline Internal awareness & 0.86 & 0.86 & 0.91 & 0.78 \\
\hline Suppliers' pressure & 0.88 & 0.89 & 0.92 & 0.74 \\
\hline Customers awareness & 0.81 & 0.83 & 0.89 & 0.73 \\
\hline Regulations pressure & 0.78 & 0.79 & 0.87 & 0.70 \\
\hline GSCM practice & 0.88 & 0.88 & 0.93 & 0.81 \\
\hline GSCM performance & 0.86 & 0.86 & 0.91 & 0.78 \\
\hline
\end{tabular}

Table 4: Discriminant validity

\begin{tabular}{|l|c|c|c|c|c|c|}
\hline & $\begin{array}{c}\text { Internal } \\
\text { awareness }\end{array}$ & $\begin{array}{c}\text { Suppliers' } \\
\text { pressure }\end{array}$ & $\begin{array}{c}\text { Customers } \\
\text { awareness }\end{array}$ & $\begin{array}{c}\text { Regulations } \\
\text { pressure }\end{array}$ & $\begin{array}{c}\text { GSCM } \\
\text { practice }\end{array}$ & $\begin{array}{c}\text { GSCM } \\
\text { performance }\end{array}$ \\
\hline Internal awareness & 0.88 & & & & & \\
\hline Regulations pressure & 0.55 & 0.84 & & & & \\
\hline Suppliers' pressure & 0.57 & 0.56 & 0.86 & & & \\
\hline Customers awareness & 0.51 & 0.59 & 0.85 & 0.82 & & \\
\hline GSCM practice & 0.55 & 0.57 & 0.54 & 0.54 & 0.90 & \\
\hline GSCM performance & 0.65 & 0.53 & 0.55 & 0.56 & 0.68 & 0.88 \\
\hline
\end{tabular}


Table 5: VIF, $\mathrm{f}^{2}, \mathrm{R}^{2}$ và $\mathrm{R}^{2}$ Adjusted value

\begin{tabular}{|c|c|c|c|c|c|c|c|c|c|c|c|c|}
\hline & \multicolumn{2}{|c|}{$\begin{array}{c}\text { Internal } \\
\text { awareness }\end{array}$} & \multicolumn{2}{|c|}{$\begin{array}{l}\text { Customers } \\
\text { awareness }\end{array}$} & \multicolumn{2}{|c|}{$\begin{array}{l}\text { Suppliers' } \\
\text { pressure }\end{array}$} & \multicolumn{2}{|c|}{$\begin{array}{c}\text { Regulations } \\
\text { pressure }\end{array}$} & \multicolumn{2}{|c|}{$\begin{array}{c}\text { GSCM } \\
\text { practice }\end{array}$} & \multirow[t]{2}{*}{$\mathbf{R}^{2}$} & \multirow[t]{2}{*}{$\begin{array}{c}\mathbf{R}^{2} \\
\text { Adjustec }\end{array}$} \\
\hline & (VIF) & $\mathbf{f}^{2}$ & (VIF) & $f^{2}$ & (VIF) & $\mathbf{f}^{2}$ & (VIF) & $\mathbf{f}^{2}$ & (VIF) & $f^{2}$ & & \\
\hline $\begin{array}{l}\text { GSCM } \\
\text { practice }\end{array}$ & 1.88 & 0.09 & 1.89 & 0.042 & 1.97 & 0.039 & 2.10 & 0.02 & - & - & 0.56 & 0.57 \\
\hline $\begin{array}{l}\text { GSCM } \\
\text { performance }\end{array}$ & 1.95 & 0.141 & 1.97 & 0.02 & 2.05 & 0.018 & 2.16 & 0.013 & 1.80 & 0.20 & 0.44 & 0.45 \\
\hline
\end{tabular}

Table 6: Hypothesis result

\begin{tabular}{|c|c|c|c|c|c|c|c|}
\hline & & $\begin{array}{c}\text { Original } \\
\text { Sample (0) }\end{array}$ & $\begin{array}{c}\text { Sample } \\
\text { Mean (M) }\end{array}$ & $\begin{array}{c}\text { Standard } \\
\text { Deviation (STDEV) } \\
\end{array}$ & $\begin{array}{l}\text { T Statistics } \\
\text { (|O/STDEV|) }\end{array}$ & P Values & \begin{tabular}{|c|c|}
$\begin{array}{c}\text { Hypothesis } \\
\text { result }\end{array}$ \\
\end{tabular} \\
\hline $\begin{array}{l}\text { Internal awareness } \\
\text { GSCM practice }\end{array}$ & $\rightarrow$ & 0.20 & 0.19 & 0.07 & 2.88 & 0.00 & \multirow{2}{*}{ Supported } \\
\hline $\begin{array}{l}\text { Internal awareness } \\
\text { GSCM performance }\end{array}$ & $->$ & 0.28 & 0.28 & 0.06 & 4.93 & 0.00 & \\
\hline $\begin{array}{l}\text { Suppliers' pressure } \\
\text { GSCM practice }\end{array}$ & $->$ & 0.22 & 0.22 & 0.08 & 2.69 & 0.01 & \multirow{2}{*}{$\begin{array}{c}\text { Partly } \\
\text { Supported }\end{array}$} \\
\hline $\begin{array}{l}\text { Suppliers' pressure } \\
\text { GSCM performance }\end{array}$ & $->$ & 0.01 & 0.01 & 0.05 & 0.18 & 0.86 & \\
\hline $\begin{array}{l}\text { Customers awareness } \\
\text { GSCM practice }\end{array}$ & -> & 0.21 & 0.21 & 0.07 & 3.16 & 0.00 & \multirow{2}{*}{ Supported } \\
\hline $\begin{array}{l}\text { Customers awareness } \\
\text { GSCM performance }\end{array}$ & $->$ & 0.12 & 0.12 & 0.06 & 2.04 & 0.04 & \\
\hline $\begin{array}{l}\text { Regulations pressure } \\
\text { GSCM practice }\end{array}$ & $->$ & 0.17 & 0.18 & 0.07 & 2.62 & 0.01 & \multirow{2}{*}{$\begin{array}{c}\text { Partly } \\
\text { Supported }\end{array}$} \\
\hline $\begin{array}{l}\text { Regulations pressure } \\
\text { GSCM performance }\end{array}$ & $->$ & 0.09 & 0.09 & 0.06 & 1.69 & 0.09 & \\
\hline $\begin{array}{l}\text { GSCM practice } \\
\text { GSCM performance }\end{array}$ & $->$ & 0.40 & 0.39 & 0.05 & 7.44 & 0.00 & Supported \\
\hline
\end{tabular}

$\mathrm{H}_{2}$ estimations for the relationships of the suppliers' pressure with GSCM practice and GSCM performance are partly supported, while suppliers' pressure have a positive relationship with GSCM practice $(\beta=0.22, \mathrm{t}=2.69, \mathrm{P}$ $<0.01$ ). However, suppliers' pressure has no positive relationship with GSCM performance $(\mathrm{P}>0.01)$. This result indicates that the developing environmentally-friendly goods suppliers have an impact on GSCM practice, however it is not the cause of GSCM performance (Cousins et al., 2019; Le, 2020).

The results of $\mathrm{H}_{3}$ shows the positive relationship between customers' awareness and GSCM practice $(\beta=0.21, \mathrm{t}=3.16$, $\mathrm{P}<0.01)$ and the relationship between customers' awareness and GSCM performance $(\beta=0.12, \mathrm{t}=2.04, \mathrm{P}<0.01)$. This result indicates the sensitive meaning while customers' awareness of green product impacts on both GSCM practice and GSCM performance of companies. As Le (2020) and Tseng et al. (2019) indicated the role of customer.

The $\mathrm{H}_{4}$ results also are partly supported by the model when the prediction of relationship between regulations pressure and GSCM practice are supported $(\beta=0.17, \mathrm{t}=$ $2.62, \mathrm{P}<0.01$ ), while the prediction of relationship between regulations pressure and GSCM performance is not supported $(\mathrm{P}>0.05)$. This result notes that regulations from all level may make the company practice the GSCM, but may not have the result of GSCM performance or some time it may come from the way company practice.

Finally, the testing of the relationship between GSCM practice and GSCM performance has been verified and is supported $\left(\mathrm{H}_{5}: \beta=0.4, \mathrm{t}=7.44, \mathrm{P}<0.01\right)$. 


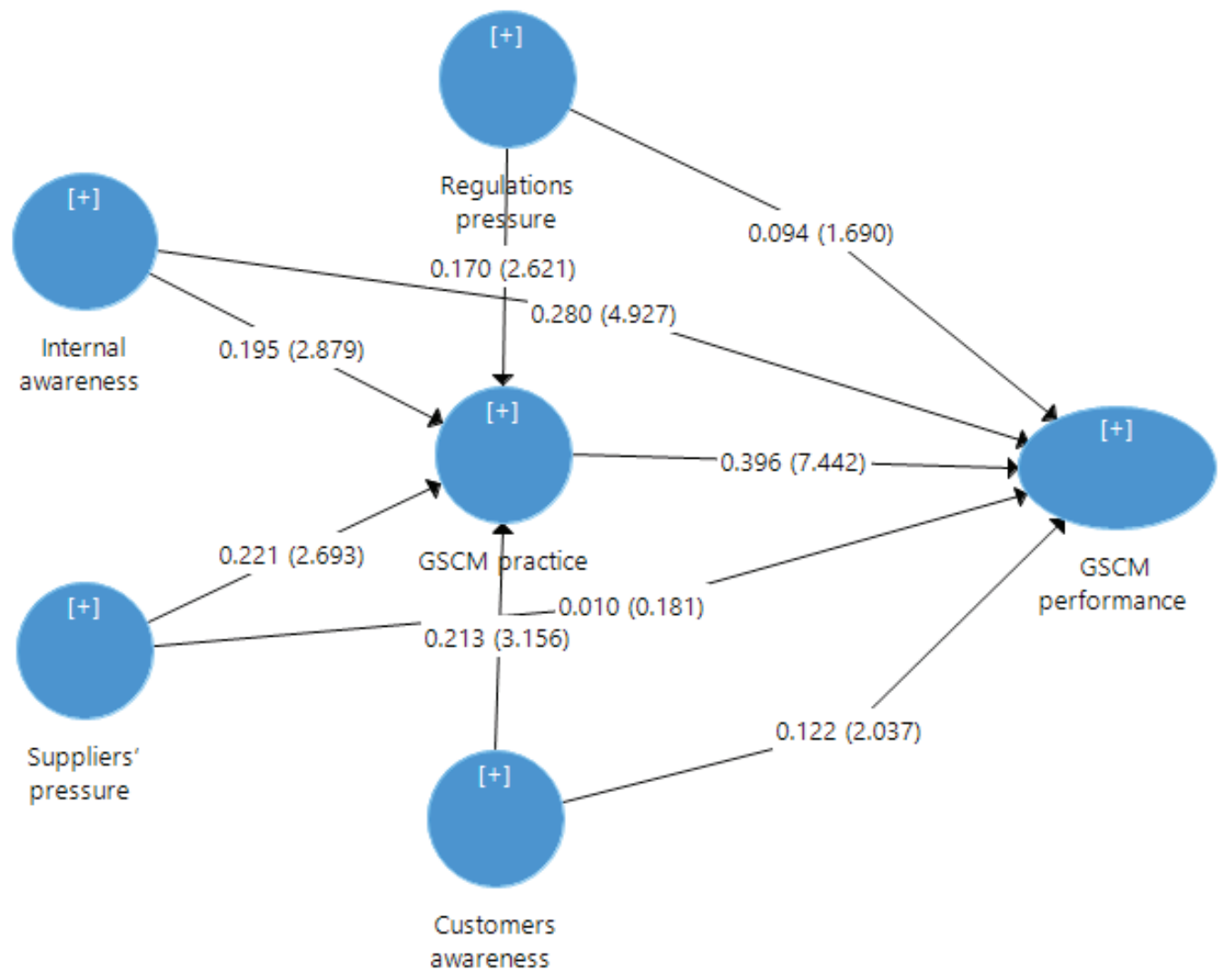

Figure 1: Research model result

\section{Conclusions}

This study provides a framework for understanding the inter relationships among four factors: internal awareness, suppliers' pressure, customers' awareness; regulations pressure; and their effect on GSCM practice, and GSCM performance. By using the PLS- SEM method, this study adds empirical support to the literature and has tested five hypotheses related to the GSCM practice and evaluative factors affecting the GSCM performance of companies in the industry zone of Province-Level in Vietnam. According to the results in this study, three out of five hypotheses are fully supported and two hypotheses are partly supported. Regarding hypothesis $\mathrm{H} 1$, the result indicates that internal awareness is positively related to the GSCM practice and GSCM performance. This finding corroborates the findings by Zhu et al. (2008), Cousins et al. (2019), and Abdel-Baset et al. (2019) that the internal awareness of senior managers, middle managers and functional managers has strong impact on GSCM practice and GSCM performance.

However, this study shows that suppliers' pressure and regulations pressure impact on GSCM practice. It is reasonable since this pressure is external to the company and require it to face this pressure (Chen et al., 2019; Laari et al., 2016; Mamdouh Mahmoud Hamdy et al., 2018). The results from H3 show that customers' awareness has a positive effect on both GSCM practice and GSCM performance. This result indicates the important role of customers in impacting on the GSCM practice attitude of company, and also providing benefits to the company related to its GSCM performance activities (Esfahbodi et al., 2016; Laari et al., 2016; Mamdouh Mahmoud Hamdy et al., 2018; Gandhi et al., 2019).

The findings of this study can help manager of companies in industrial zone to understand the structure of GSCM, associate with the GSCM practice and green supply chain management performance, and be successful in green management organizations. Internal awareness and customer awareness are important factors improving GSCM practice and performance by creating and fulfilling all levels of managers and customer awareness. When managers understand how GSCM can benefit them, they can create more effective campaigns to implement the practice. Our findings could help manager of industrial zone to understand better the structure of GSCM and to identify the related core impacting factor. In addition, suppliers and regulations are 
also the two importance external factors that make for better GSCM practice.

Although this study contributes to the theoretical and managerial implications, the model used in this study should be more developed regarding other impacting factors in the future. Namely, another construct could be introduced and tested as it may have a strong impact on GSCM practice and performance. Also, future studies with larger samples could be conducted to allow for comparisons among companies in other industrial zones in Vietnam.

\section{References}

Abdel-Baset M., Chang V. and Gamal A. (2019). Evaluation of the green supply chain management practices: A novel neutrosophic approach. Computers in Industry, 108, 210-220.

Alves, A. P. F., Nascimento, L. F.M.DO. (2014). Green Supply Chain: a protagonist or a supporting role in Brazil? Business Administration Magazine, 54(5), 510-520.

An, H. K., Amano, T., Utsumi, H., \& Matsui, S. (2008). A framework for green supply chain management complying with RoHS directive. Belfast, UK: Queen's University.

Balasubramanian, S. and Shukla, V. (2017). Green supply chain management: an empirical investigation on the construction sector. Supply Chain Management, 22(1), 58-81.

Bhool, R. and Narwal, M. S. (2013). An analysis of drivers affecting the implementation of green supply chain management for the Indian manufacturing industries. International Journal of Research in Engineering and Technology, 2(11), 242-254.

Cagno, E., De Ambroggi, M. and Trucco, P. (2011). Interdependency analysis of CIs in real scenarios', in Bérenguer, G. and Guedes, S. (Eds.): Proceedings of ESREL 2011 - Advances in Safety, Reliability and Risk Management, 2508-2514, Taylor \& Francis Group, London, ISBN 978-0-415-68379-1.

Chen, D., Ignatius, J., Sun, D., Zhan, S., Zhou, C., Marra, M., and Demirbag, M. (2019). Reverse logistics pricing strategy for a green supply chain: A view of customers' environmental awareness. International Journal of Production Economics, 217, 197-210.

Chien, M. K., and Shih, L. H. (2007). An Empirical study of the implementation of green supply chain management practice in the electrical and electronic industry and their relation to organize performances, International Journal of Environmental Science and Technology, 4(3), 383-394.

Cousins, P., Lawson, B., Petersen, K. and Fugate, B. (2019). Investigating green supply chain management practices and performance: The moderating roles of supply chain ecocentricity and traceability. International Journal of Operations \& Production Management, 39(5), 767-786.

De Giovanni, P., and Vinzi, V. E. (2012). Covariance versus component-based estimations of performance in green supply chain management. International Journal of Production Economics, 135(2), 907-916.
Diabat, A., and Govindan, K. (2011). An analysis of the drivers affecting the implementation of green supply chain management. Resources, Conservation and Recycling, 55(6), 659-667.

Do, A.D. and Luu, H.V. (2019). Developing a quality function deployment method for selecting and evaluating suppliers. Journal of Economics and Development, 262(4), 80-88.

Do, A.D., Nguyen, Q.V., Nguyen D.U., Le Q.H. and Trinh, D.U. (2020), Green supply chain management practices and destination image: Evidence from Vietnam tourism industry. Uncertain Supply Chain Management, 8, 371-378.

Esfahbodi, A., Zhang, Y., and Watson, G. (2016). Sustainable supply chain management in emerging economies: Trade-offs between environmental and cost performance. International Journal of Production Economics, 181, 350-366.

Gandhi M., Vasudevan H. (2019) Green Supply Chain Management Practices and Its Impact on Business Performance. In: Vasudevan H., Kottur V., Raina A. (eds) Proceedings of International Conference on Intelligent Manufacturing and Automation. Lecture Notes in Mechanical Engineering. Springer, Singapore

Green, K., Zelbst, P., Meacham, J. and Bhadauria, V. (2012). Green supply chain management practices: impact on performance. Supply Chain Management, 17(3), 290-305.

Hair Jr, J.F., Black W.C., Babin B.J., and Anderson R.E (2014). Multivariate Data Analysis. London, UK: Pearson Education Limited.

Hair Jr, J.F., Hult, G. T. M., Ringle, C. and Sarstedt, M. (2016). A primer on partial least squares structural equation modeling (PLS-SEM). New York, NY: Sage publications.

Ho, J. C., Shalishali, M. K., Tseng, T. and Ang, D. S. (2009). Opportunities in green supply chain management. The Coastal Business Journal, 8(1), 18-31.

Holt, D. and Ghobadian, A. (2009). An empirical study of green supply chain management practices amongst UK manufacturers. Journal of Manufacturing Technology Management, 20(7), 933-956.

Huynh, T.T.S (2017). Factors Impacting on the Supply Chain Collaboration of the Furniture Industry in Vietnam. The Journal of Asian Finance, Economics and Business, 4(4), 67-77. http:// dx.doi.org/10.13106/jafeb.2017.vol4.no4.67

Jain, V. K. and Sharma, S. (2014). Drivers Affecting the Green Supply Chain Management Adaptation: A Review. IUP Journal of Operations Management, 13(1), 54-63.

Jang, Y. J., Kim, W. G. and Lee, H. Y. (2015). Coffee shop consumers' emotional attachment and loyalty to green stores: The moderating role of green consciousness. International Journal of Hospitality Management, 44, 146-156.

Laari, S., Töyli, J., Solakivi, T. and Ojala, L. (2016). Firm performance and customer-driven green supply chain management. Journal of Cleaner Production, 112(3), 19601970. 
Laosirihongthong, T., Adebanjo, D. and Choon Tan, K. (2013). Green supply chain management practices and performance. Industrial Management \& Data Systems, 113(8), 1088-1109.

Le, T.T. (2020). The effect of green supply chain management practices on sustainability performance in Vietnamese construction materials manufacturing enterprises. Uncertain Supply Chain Management, 8(1), 43-54.

Lee J. W. \& Tan, W. N (2019). Global Corporate Citizenship: Cross-cultural Comparison of Best Practices in the Global Automotive Industry. Journal of Asian Finance, Economics and Business, 6(1), 261-271. https://doi.org/10.13106/jafeb.2019. vol6.no1.261

Lee, C. \& Ha, B.C. (2020). The Impact of Interactional Justice and Supply-Chain Collaboration on Sustainable SCM Performance: The Case of Multinational Pharmaceutical Firms. Journal of Asian Finance, Economics and Business, 7(2), 237-247. https:// doi.org/10.13106/jafeb.2020.vol7.no2.237

Lee, S. (2008). Drivers for the participation of small and mediumsized suppliers in green supply chain initiatives. Supply Chain Management, 13(3), 185-198.

Lin, R. J. (2013). Using fuzzy DEMATEL to evaluate the green supply chain management practices. Journal of Cleaner Production, 40, 32-39.

Majumdar, A. and Sinha, S. K. (2019). Analyzing the barriers of green textile supply chain management in Southeast Asia using interpretive structural modeling. Sustainable Production and Consumption, 17, 176-187.

Mamdouh Mahmoud Hamdy, O., Kadry Elsayed, K. and Elahmady, B. (2018). Impact of Sustainable Supply Chain Management Practices on Egyptian Companies' Performance. European Journal of Sustainable Development, 7(4), 119-130.

Narasimhan, R. and Carter, J. R. (1998). Linking business unit and material sourcing strategies. Journal of Business Logistics, 19(2), 155-171.

Nguyen, Q.V, Tran V.T and Nguyen V.A. (2014). Willingness to apply the green supply chain management in hotel industry. Global Journal of Advanced Research, 2(1), 321-334.

Nguyen, T.A (2019). An investigation into the relationship between materialism and green purchase behavior in Vietnam and Taiwan. Journal of Economics and Development, 21(2), 247258.

Pham, T.L \& Hoang, V.H (2019). The relationship between organizational learning capability and business performance: The case of Vietnam firms. Journal of Economics and Development, 21(2), 259-271.
Ricky Y. K. Chan and Lorett B. Y. Lau (2002). Explaining Green Purchasing Behavior. Journal of International Consumer Marketing, 14 (2-3), 9-40, DOI: 10.1300/J046v14n02_02

Shults II, C.J and Holbrook, M.B. (1999). Marketing and the Tragedy of the Commons: A Synthesis, Commentary, and Analysis for Action. Journal of Public Policy and Marketing, 18(2), 218-229.

Sundarakani, B., De Souza, R., Goh, M., Van Over, D., Manikandan, S. and Lenny Koh, S. C. (2010). A sustainable green supply chain for globally integrated networks. Enterprise Networks and Logistics for Agile Manufacturing, (191-206). Springer, London.

Tseng, M. L., Islam, M. S., Karia, N., Fauzi, F. A. and Afrin, S. (2019). A literature review on green supply chain management: Trends and future challenges. Resources, Conservation and Recycling, 141, 145-162.

Vachon, S. and Klassen, R. D. (2006). Extending green practices across the supply chain: the impact of upstream and downstream integration. International Journal of Operations \& Production Management, 26(7), 795-821.

Vietnam Logistics Review (2015). Green supply chain management. Retrieved March 30, 2020, from http://vlr.vn/doanh-nghiep/ news-2152.vlr

Vijayakumar, N., Sridharan, P., \& Rao, K. C. S. (2010). Determinants of FDI in BRICS Countries: A panel analysis. International Journal of Business Science \& Applied Management, 5(3), 1-13.

Wang, J. and Dai, J. (2018). Sustainable supply chain management practices and performance. Industrial Management \& Data Systems, 118(1), 2-21

$\mathrm{Xu}, \mathrm{X}$. and Gursoy, D. (2015). Influence of sustainable hospitality supply chain management on customers' attitudes and behaviors. International Journal of Hospitality Management, 49, 105-116.

Xue, C. (2014). Diffusion behavior and analysis of the green manufacturing mode under the influence of government. Journal of Computers, 9(1),89-94.

Zhu, Q. and Sarkis, J. (2004). Relationships between operational practices and performance among early adopters of green supply chain management practices in Chinese manufacturing enterprises. Journal of Operations Management, 22(3), 265-289.

Zhu, Q., Sarkis, J., Lai, K. H. and Geng, Y. (2008). The role of organizational size in the adoption of green supply chain management practices in China. Corporate Social Responsibility and Environmental Management, 15(6), 322-337. 